\title{
Cell Saver device efficiently removes cell-derived microparticles during cardiac surgery
}

Jeanette M. van den Goor, MSc, ${ }^{\text {a }}$ Rienk Nieuwland, $\mathrm{PhD},{ }^{\mathrm{b}}$ Willem van Oeveren, $\mathrm{PhD},{ }^{\mathrm{d}}$ Peter M. Rutten, ${ }^{\mathrm{a}}$ Jan G. Tijssen, MSc, PhD, ${ }^{c}$ Chi M. Hau, BSc, ${ }^{b}$ Augueste Sturk, PhD, ${ }^{b}$ León Eijsman, MD, PhD, ${ }^{a}$ and Bas A. de Mol, MD, PhD, Amsterdam and Groningen, The Netherlands

A $\mathrm{t}$ the end of cardiac procedures assisted by cardiopulmonary bypass (CPB), a large volume of diluted blood $(0.75-1.5 \mathrm{~L})$ remains within the extracorporeal circuit. To reduce transfusion requirements, this blood can be used for autotransfusion with or without processing. One of the options for processing is the use of a Cell Saver device (Haemonetics, Braintree, Mass) that concentrates erythrocytes and discards plasma. During CPB, elevated numbers of cell-derived vesicles, microparticles, are present that promote coagulation and inflammation. ${ }^{1}$ The aim of this study was to determine the effects of a Cell Saver device on microparticle counts during a cardiac operation. Heparin and prothrombin fragment $\mathrm{F}_{1+2}$ were measured as controls for the efficient removal of low-molecular-weight substances.

From the Departments of Cardio-thoracic Surgery, ${ }^{\text {a }}$ Experimental Clinical Chemistry, ${ }^{\mathrm{b}}$ and Cardiology, ${ }^{\mathrm{c}}$ Academic Medical Center of the University of Amsterdam, Amsterdam, The Netherlands, and the Department of Biomedical Engineering, ${ }^{\mathrm{d}}$ University Medical Center Groningen, Groningen, The Netherlands.

Received for publication Feb 2, 2007; accepted for publication Feb 8, 2007.

Address for reprints: Jeanette M. van den Goor, MSc, Department of Cardio-thoracic Surgery, Academic Medical Center of the University of Amsterdam, Meibergdreef 9, 1105 AZ Amsterdam, The Netherlands (E-mail: J.M.vandenGoor@amc.nl).

J Thorac Cardiovasc Surg 2007;134:798-9

$0022-5223 / \$ 32.00$

Copyright $\odot 2007$ by The American Association for Thoracic Surgery doi:10.1016/j.jtcvs.2007.02.042

\section{Patients and Methods}

Patients for elective coronary artery bypass grafting assisted by CPB $(n=13)$ were included after signed informed consent. This study was approved by the Medical Ethics Committee of the Academic Medical Center (Amsterdam, The Netherlands). Blood was collected before and after processing with a Cell Saver device (Cell Saver 5). Cell counts were determined on a CellDyn 4000 hematology analyzer (Abbott, Mijdrecht, The Netherlands). Microparticles, prothrombin fragment $\mathrm{F}_{1+2}$, and heparin were determined as described previously., ${ }^{2,3}$ Concentrations of heparin, microparticles, and $\mathrm{F}_{1+2}$ were corrected for hematocrit. Data were analyzed with SPSS version 11.0 (SPSS, Inc, Chicago, Ill) and presented as medians (interquartile range). The paired-samples $t$ test or Wilcoxon signed rank test was used whenever appropriate.

\section{Results and Discussion}

All data are summarized in Table 1. Processing with the Cell Saver device decreased blood volume about 2-fold from $850 \mathrm{~mL}$ to 440 $\mathrm{mL}$. As expected, the hematocrit value increased from 0.26 (before) to 0.55 (after cell salvage; $P<.001$ ). The recovery of the erythrocytes was almost $100 \%(P=.161)$. In contrast, about $89 \%$ of the platelets $(P<.001)$ and $31 \%$ of the leukocytes $(P<.001)$ were removed by the Cell Saver device. Small molecules like heparin and $\mathrm{F}_{1+2}$ were removed efficiently by $100 \%(P<.001)$ and $98 \%(P=.003)$, respectively. The data demonstrating the efficiency of the Cell Saver device to recover erythrocytes and to remove platelets, leukocytes, and heparin are all in close agreement with data provided by the manufacturer in the Cell Saver 5 Equivalence Validation Report of September 20, 1993 (95.8\%

TABLE 1. Cell Saver device data

\begin{tabular}{|c|c|c|c|c|}
\hline & \multicolumn{2}{|c|}{ Cell Saver device } & \multirow[b]{2}{*}{ Removal (\%) } & \multirow[b]{2}{*}{$P$ value } \\
\hline & Before & After & & \\
\hline Volume (mL) & $850(796-934)$ & $440(323-481)$ & $53(46-63)$ & $<.001$ \\
\hline Hematocrit (L/L) & $0.26(0.24-0.26)$ & $0.55(48-0.60)$ & NA & $<.001$ \\
\hline Erythrocytes (mL) & $217(199-246)$ & 199 (178-253) & $3(-5-17)$ & .161 \\
\hline Thrombocytes $\left(10^{9}\right)$ & $140(85-179)$ & $16(10-21)$ & $89(79-91)$ & $<.001$ \\
\hline Leukocytes $\left(10^{9}\right)$ & $4.7(3.1-6.0)$ & $3.8(1.5-4.0)$ & 31 (18-45) & $<.001$ \\
\hline Heparin $\left(10^{3} \mathrm{IU}\right)$ & 1765 (1666-2053) & $9(4-11)$ & $100(99-100)$ & $<.001$ \\
\hline $\mathrm{F}_{1+2}(\mathrm{nmol})$ & $2.47(0.50-7.39)$ & $0.04(0.03-0.05)$ & 98 (92-99) & .003 \\
\hline EryMP $\left(10^{7}\right)$ & $128(37-292)$ & $5(2-5)$ & 97 (86-99) & .002 \\
\hline $\operatorname{PMP}\left(10^{7}\right)$ & 147 (93-191) & $1(1-2)$ & 99 (98-99) & $<.001$ \\
\hline
\end{tabular}

Data are presented as medians (interquartile ranges). $N A$, Not applicable; $F_{1+2}$, prothrombin fragment; EryMP, erythrocyte-derived microparticles; $P M P$, platelet-derived microparticles. 
erythrocyte recovery; $82 \%$ and $24.3 \%$ for platelets and leukocytes, respectively; $97.8 \%$ for heparin).

Cell-derived microparticles are, on average, smaller in diameter than platelets and range in size from about $100 \mathrm{~nm}$ to $1.0 \mu \mathrm{m}$. Thus, the largest microparticles may overlap in size with platelets, which on average range in from $1.0 \mu \mathrm{m}$ to $5.0 \mu \mathrm{m}$. Both erythrocyte-derived microparticles and platelet-derived microparticles were removed efficiently (97\% and 99\%; $P=0.002$ and $P<.001$, respectively). Interestingly, the efficiency of the Cell Saver device to remove platelet-derived microparticles as well as erythrocyte-derived microparticles was significantly increased compared with the efficiency to remove thrombocytes $(P=.019$ and $P=.002$, respectively; Wilcoxon signed rank test). Thus, cell-derived vesicles, which on average are smaller in diameter than thrombocytes, are removed more efficiently from blood by a Cell Saver device than thrombocytes in a clinical setting.

This study is the first to directly evaluate the efficiency of a Cell Saver device to remove cell-derived microparticles from patient blood. Our data show that a Cell Saver device efficiently reduces the numbers of coagulation- and inflammation-promoting microparticles. From these data we cannot exclude that microparticles may bind to cells present within the blood or that low numbers of microparticles are generated by cell activation during the passage of blood through the Cell Saver device.

\section{References}

1. Nieuwland R, Berckmans RJ, Rotteveel-Eijkman RC, Maquelin KN, Roozendaal KJ, Jansen PG, et al. Cell-derived microparticles generated in patients during cardiopulmonary bypass are highly procoagulant. Circulation. 1997;96:3534-41.

2. van Putten J, van de Ruit M, Beunis M, Hemker HC. Automated determination of heparin with chromogenic substrates. Haemostasis. 1984;14:184-94.

3. Berckmans RJ, Nieuwland R, Boing AN, Romijn FP, Hack CE, Sturk A. Cell-derived microparticles circulate in healthy humans and support low grade thrombin generation. Thromb Haemost. 2001;85:639-46.

\title{
Primary intrapulmonary thymoma associated with congenital hyperhomocysteinemia
}

\author{
Alessando Stefani, MD, ${ }^{a}$ Edouard Boulenger, MD, ${ }^{\mathrm{b}}$ Sylvie Mehaut, MD, ${ }^{\mathrm{c}}$ Adrian Ciupea, $\mathrm{MD},{ }^{\mathrm{c}}$ and Marco Alifano, MD, \\ Paris and Troyes, France
}

$\mathrm{P}$ rimary intrapulmonary thymomas (PITs) are very uncommon, with 28 cases reported to date. ${ }^{1-3}$ Because of the paucity of studies, the biologic behavior and pathologic features of these neoplasms are not well known. The C677T methylenetetrahydrofolate reductase (MTHFR) genotype is a congenital disorder leading to low folate levels; the resultant mild hyperhomocysteinemia is associated with increased risk of venous thromboembolism and malignancies. ${ }^{4,5}$

We present a case of PIT associated with hyperhomocysteinemia caused by the $\mathrm{C} 677 \mathrm{~T}$ variant of MTHFR.

\section{Clinical Summary}

A 73-year-old woman was admitted for acute dyspnea with bronchospasm in a chronic obstructive pulmonary disease pathologic

From the Department of Thoracic Surgery, ${ }^{\text {a }}$ Hôtel-Dieu University Hospital, Paris, France; and the Departments of Thoracic Surgery ${ }^{\mathrm{b}}$ and Pathology, ${ }^{\mathrm{c}}$ Hospital of Troyes, Troyes, France.

Received for publication Feb 24, 2007; accepted for publication March 29, 2007.

Address for reprints: Alessandro Stefani, MD, Department of Thoracic Surgery, Hôtel Dieu University Hospital, 1, Place du Parvis Notre Dame, 75001, Paris, France (E-mail: stefani.alessandro@unimore.it).

J Thorac Cardiovasc Surg 2007;134:799-801

$0022-5223 / \$ 32.00$

Copyright $\odot 2007$ by The American Association for Thoracic Surgery doi:10.1016/j.jtcvs.2007.03.052 substrate. Her medical history was marked by episodes of venous thrombosis caused by a mutation of the MTHFR gene that imposed a preventive anticoagulant therapy. Chest radiography revealed an 18-mm nodule in the right upper lobe, which was confirmed by a computed tomographic scan (Figure 1). A positron emission tomographic scan showed a moderate uptake in correspondence of the lesion (standardized uptake value, 2.2). The results of bronchoscopy and computed tomographic scanning of the brain were normal.

A primary pulmonary tumor was suspected. Thoracotomy was performed by one of us (E.B.), and a nodule was found in the right upper lobe close to the hilum. Frozen examination revealed cells of uncommon feature suspected for malignancy. A right upper lobectomy with full nodal dissection was performed.

Macroscopic examination showed a well-circumscribed and encapsulated nodule (Figure 2, a). Histologic evaluation revealed the presence of 2 cell populations: epithelioid and lymphocytic (Figure 2,b). The epithelioid component was predominant and admixed with scattered lymphocytes. No areas of necrosis and very few mitoses could be identified. Immunohistochemical analysis demonstrated strong staining for cytokeratin 5 and 6 and epithelial membrane antigen in the epithelioid component, with negative staining for cytokeratin 7 , thyroid transcription factor 1 , and calretinine. These histologic findings were consistent with mixed or type $\mathrm{AB}$ thymoma. All lymph nodes were free of tumor.

The postoperative course was uneventful, and the patient is free of recurrence 2 years after the operation. 